\title{
Transformation of the Scientific Paradigm of Leadership Under the Influence of Digital Reality
}

\author{
Alyona Gubanova, Oksana Mineva, and Elena Gadzhieva* \\ Astrakhan State University, Astrakhan, Russia
}

\begin{abstract}
Leadership is a kind of integrator of the problems of modern management science and practice, which leads to a continuing interest in the study of the personality of the leader and the models of his behavior and activities in modern society, in the management of organizations and processes. At the turn of the XX-XXI centuries, research in the field of leadership is very actively continuing, however, in general, it has changed its direction, shifting attention to the personality of the leader, the possibilities of his self-development and self-improvement for more effective leadership, internal motivation, the authenticity of the leader and his behavior, which was facilitated by the systemic crisis in business in developed countries, global problems of our time, the transition from the industrial economy to the knowledge economy. The article defines the fundamental differences in the leadership models of the industrial economy and the knowledge economy, and describes modern approaches to the study of leadership. It is revealed that modern leadership studies somehow develop the main directions of the study of leaders and leadership, set by classical concepts, but at the same time have significant distinctive trends that have formed in recent decades: the desire for collective leadership, the transition from transactional to transformational leadership, the development of leadership «deep» in the direction of self-motivation of the leader, a largely irrational approach to leadership.
\end{abstract}

\section{Problem statement}

The phenomenon of leadership has been one of the most widely discussed and developed problems in management and other sciences, such as psychology, sociology, and political science, for about 150 years. Leadership is the oldest form of organizing the life of human communities, since it lies in the very nature of society and man, reflecting one of the most general social laws and the objective needs of society, such as the need for social and cultural self-regulation, self-organization, ordering of individual elements of the social system in order to ensure its vital and functional ability. Today, leadership is a kind of integrator of the problems of modern management science and practice, which leads to a continuing interest in the study of the personality of the leader and the models of his

\footnotetext{
* Corresponding author: beliki@mail.ru
} 
behavior and activities in modern society, in the management of organizations and processes.

\section{Analysis of publications}

In Russian science, quite a lot of research works by authoritative authors are devoted to the systematization of views on the problem of leadership. We can note the works of such authors as S.R. Filonovich [1, 2], O.S. Vihansky and A.G. Mirakyan [3], A.L. Zamulin [4], E.O. Karpinskaya, G.V. Shirokova [5], T.A. Krylova [6], L.M. Mosin, D.P. Veselovsky [7], M.V. Romanov [8], S.A. Sergeev [9], O.K. Slinkov [10] and others. At the same time, Russian and foreign researchers pay special attention to the study of the evolution of theories and problems of leadership in order to identify the main trends and prospects for development. At the same time, heretofore an unambiguous understanding of this phenomenon has not been formulated, and it is obvious that there is no universal theory of leadership, since this concept is multi aspect. The concept of leadership has such a characteristic as dualism, since, on the one hand, leadership is a position of the individual (static aspect), and on the other - the process of involving the leader of followers in a certain purposeful activity (process aspect) [2]. It is precisely by ignoring the inseparability of the two aspects of leadership that the limitations of many leadership concepts are explained.

\section{Formulation of the purpose of the work}

The purpose of this study is to conduct a comparative analysis of modern concepts of leadership in management science, to identify their relationship with classical theories, to identify the main trends and problems. The need for research is due to the fact that at the turn of the XX-XXI centuries, research in the field of leadership is very actively continuing, however, in general, it has changed its direction.

The main research methods are: theoretical analysis of scientific sources devoted to the topic of leadership; comparative-historical method; comparative analysis and a systematic approach.

The theoretical basis for the study was the work of many outstanding management theorists of the XX century, as well as a number of domestic specialists in the field of management and leadership.

\section{Main part}

Research in the field of leadership became quite active in the late XX and early XXI centuries, changing its overall direction and shifting attention to the personality of the leader, the possibilities of his self-development and self-improvement for more effective leadership, internal motivation, the authenticity of the leader and his behavior [11], which was facilitated by the systemic crisis in business in developed countries, global problems of our time, the transition from the industrial economy to the knowledge economy. Much is said about the change in the management paradigm and the corresponding change in leadership concepts in the studies of both foreign and Russian scientists, such as W. Bennis, I. Adizes [12], O.S. Vihansky, A.I. Naumov, G.B. Kleiner, S.R. Filonovich, etc.

The fundamental differences in the management and leadership models of the industrial economy and the knowledge economy are reflected in figure 1. 


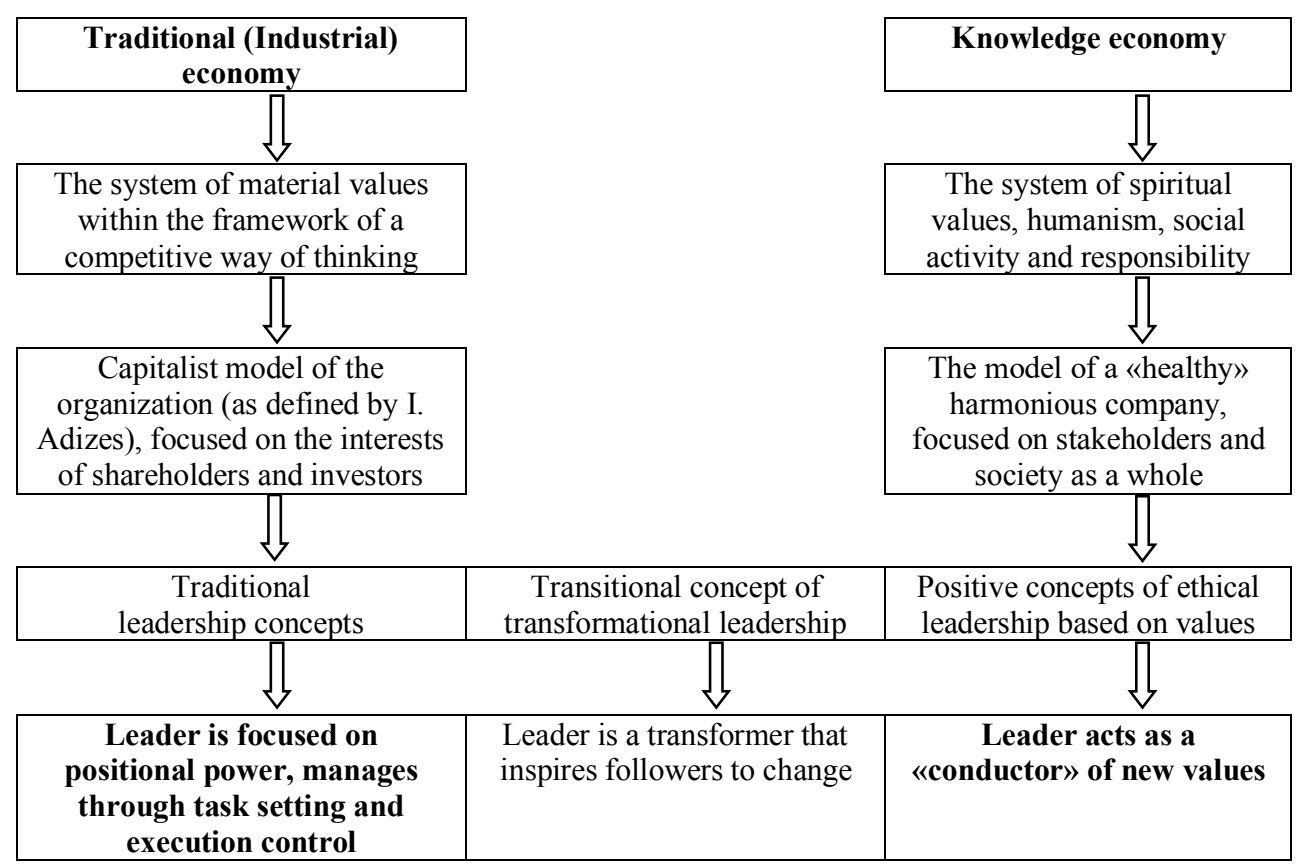

Fig. 1. Management and leadership models of the industrial economy and the knowledge economy.

As it was already revealed by the authors earlier [11], at the present stage of the development of management science, associated with the value concepts of leadership, the most common ideas are about leadership as an effective interaction of the leader and his followers, the ability to convince, the result of the distribution of roles in the group. Modern models of leadership are mainly developed by American researchers, whose interest in this problem was provoked and strengthened by loud corporate scandals in the largest American companies in the late XX and early XXI century [1, 2, 3].

The most well-known theories of leadership in recent decades include: the value theories of G. Fairholm (1995), T. and S. Kuchmarsky (1996), the theory of emotional intelligence by D. Golman (mid-1990s), the theory of indirect leadership by R. Fischer and A. Sharp (1998), the concept of «distributed» or «shared» leadership by D. Bradford and A.Cohen (1998), the theory of connecting leadership and the concept of «hot groups» by J. Lipman-Blumen (1997-2000), the theory of the «driving force of leadership» by N. Tichy (1997-2002), the theory of the «internal stimulation» of leadership by K. Cashman (2001), the concept of «primary» leadership by D. Golman and R. Boyatsis (2002), the theory of leadership through the management of paradoxes by F. Kessler. Trompenaars and C.Hampden-Turner (2002), the theory of «service leadership» by R. Greenleaf, F. Luthans, and Van Dierendonk, whose origins were laid back in the 1970s, and the main development of the theory began in 2002. The characteristics of these leadership models are presented in table 1 .

On the one hand, the modern studies on leadership presented in the table somehow develop the main directions of the study of leaders and leadership, set by classical concepts [11]. Thus, transformational leadership and the theory of emotional intelligence based on it, the concepts of «driving force of leadership» and «primary» leadership are largely a continuation of the theory of personal qualities, and partly a development of the behavioral approach. The theory of connecting leadership, along with the concept of «hot groups», develops a behavioral approach to leadership. The theory of «internal stimulation» of 
leadership is a synthetic concept that combines personal and behavioral approaches to leadership. The concept of «distributed» leadership can be attributed to the group of personality-situational theories. The theories of indirect leadership and leadership as a management of paradoxes continue the situational analysis of the leader's behavior.

Table 1. Characteristics of modern approaches to the study of leadership.

\begin{tabular}{|c|c|c|}
\hline Concepts & Representatives & Ideas \\
\hline Value theories & $\begin{array}{c}\text { G. Fairholm [13] } \\
\text { (1995), } \\
\text { T. and S. } \\
\text { Kuchmarsky } \\
\text { (1996) }\end{array}$ & $\begin{array}{l}\text { Define the dominant stable leadership values that } \\
\text { influence the relationship between the leader and his } \\
\text { followers and form the socio-cultural context in which } \\
\text { group activities take place. Leadership is seen as an } \\
\text { ongoing process in which the leader establishes values, } \\
\text { demonstrates them by his behavior, teaches followers } \\
\text { these principles, instilling in them the ability to self- } \\
\text { organize. }\end{array}$ \\
\hline $\begin{array}{c}\text { The theory of } \\
\text { emotional } \\
\text { intelligence }\end{array}$ & $\begin{array}{c}\text { D. Golman [14, } \\
15] \\
\text { (mid-1990s) }\end{array}$ & $\begin{array}{l}\text { The leader is required to understand the mental } \\
\text { processes and their emotional state, united by the } \\
\text { concept of «emotional intelligence», because the } \\
\text { possession of this system, which includes } 5 \text { components } \\
\text { - self-awareness, self-regulation, motivation, empathy, } \\
\text { social skills - will allow the leader to increase their } \\
\text { effectiveness. Leaders manage their feelings. }\end{array}$ \\
\hline $\begin{array}{l}\text { The theory of } \\
\text { indirect } \\
\text { leadership }\end{array}$ & $\begin{array}{l}\text { R. Fisher, } \\
\text { A. Sharp [16] } \\
\quad(1998)\end{array}$ & $\begin{array}{l}\text { In the development of the theory of leadership } \\
\text { substitutes, the problem of the feasibility of a leader } \\
\text { taking a formal position for the implementation of the } \\
\text { functions of managing the process and followers is } \\
\text { studied. The problem of motivating the leader's } \\
\text { behavior is posed: what is more important - the } \\
\text { leadership position or the result? }\end{array}$ \\
\hline $\begin{array}{l}\text { The concept of } \\
\text { «distributed» or } \\
\text { «shared» } \\
\text { leadership }\end{array}$ & $\begin{array}{l}\text { D. Bradford, } \\
\text { A. Cohen [17] } \\
\quad(1998)\end{array}$ & $\begin{array}{l}\text { The idea of distributed, or shared, leadership is that it is } \\
\text { not always necessary in a team or group to have an } \\
\text { absolute leader who occupies a stable position. The } \\
\text { leader can be temporary, coordinating the work of the } \\
\text { group at a certain stage, due to the demand for their } \\
\text { competence at this stage of work. Then it is replaced by } \\
\text { another leader, whose competence is more in demand at } \\
\text { a different stage. The idea is very difficult to implement } \\
\text { in practice, because it implies compliance with complex } \\
\text { conditions. }\end{array}$ \\
\hline $\begin{array}{l}\text { The theory of } \\
\text { connecting } \\
\text { leadership and } \\
\text { the concept of } \\
\text { «hot groups» }\end{array}$ & $\begin{array}{c}\text { J. Lipman- } \\
\text { Blumen }[18,19] \\
(1997-2000)\end{array}$ & $\begin{array}{c}\text { The leader in the team (group) plays the role of a link, } \\
\text { so he must have the ability to establish a connection } \\
\text { between personal goals and the goals and motivations } \\
\text { of followers. Skills of a successful leader: } \\
\text { communicative, the ability to inspire, be an example, } \\
\text { the ability to provide an exchange of views, the ability } \\
\text { to encourage people to cooperate. A leader who has the } \\
\text { skills of connecting leadership is able to create a «hot } \\
\text { group», i.e. a team of people who are passionate about } \\
\text { their work. }\end{array}$ \\
\hline $\begin{array}{l}\text { The theory of } \\
\text { «driving force of } \\
\text { leadership» }\end{array}$ & $\begin{array}{l}\text { N. Tichy [20] } \\
(1997-2002)\end{array}$ & $\begin{array}{l}\text { Developing the theory of transformational leadership, } \\
\text { N. Tichy determined that top-level leaders in an } \\
\text { organization should educate leaders at other managerial } \\
\text { levels on the basis of the so-called «transferable point } \\
\text { of view», consisting of business ideas, values and } \\
\text { emotional energy, determination, coordinated with each } \\
\text { other. }\end{array}$ \\
\hline
\end{tabular}




\begin{tabular}{|c|c|c|}
\hline $\begin{array}{l}\text { The theory of } \\
\text { «internal } \\
\text { stimulation» of } \\
\text { leadership }\end{array}$ & $\begin{array}{l}\text { K. Cashman }[21] \\
(2001)\end{array}$ & $\begin{array}{l}\text { The theory is originated on the basis of executive } \\
\text { coaching (coaching of the first persons), assumes the } \\
\text { possibility of developing leadership skills «from } \\
\text { within», i.e. internal leadership, in } 7 \text { areas: self- } \\
\text { knowledge, goal-setting, change management, } \\
\text { existence, interpersonal relationships, the ability to act, } \\
\text { finding balance. }\end{array}$ \\
\hline $\begin{array}{c}\text { The concept of } \\
\text { «primary» } \\
\text { leadership }\end{array}$ & $\begin{array}{l}\text { D. Golman, } \\
\text { R. Boyatsis [22] } \\
(2002)\end{array}$ & $\begin{array}{l}\text { The concept is based on the theory of emotional } \\
\text { intelligence and indicates the presence of a strong } \\
\text { dependence of the effective work of the staff on the } \\
\text { emotional state of the leader, in connection with which } \\
5 \text { leadership styles are identified: aimed at forming a } \\
\text { vision of the future, focused on coaching followers, } \\
\text { setting the pace of work, democratic and commanding. } \\
\text { The influence of leaders is largely based on emotional } \\
\text { contagion. }\end{array}$ \\
\hline $\begin{array}{l}\text { The theory of } \\
\text { leadership } \\
\text { through the } \\
\text { management of } \\
\text { paradoxes }\end{array}$ & $\begin{array}{l}\text { Trompenaars, } \\
\text { C. Hampden- } \\
\text { Turner [23] } \\
\quad(2002)\end{array}$ & $\begin{array}{c}\text { When carrying out activities, the leader often has to find } \\
\text { a balance between paradoxes (poles), which are } \\
\text { understood as problems that do not have an absolute } \\
\text { (unambiguous, static) solution, but require constant } \\
\text { regulation (dynamic approach). }\end{array}$ \\
\hline $\begin{array}{c}\text { The concept of } \\
\text { «service» } \\
\text { leadership }\end{array}$ & $\begin{array}{l}\text { R. Greenleaf, F. } \\
\text { Luthans, Van } \\
\text { Dierendonk [24] } \\
\quad(2002)\end{array}$ & $\begin{array}{l}\text { This ethically oriented concept is based on humanity to } \\
\text { both the internal and external environment of the } \\
\text { organization, based on spiritual and moral principles in } \\
\text { the management of the organization, the social } \\
\text { orientation of the organization, and the digital basis of } \\
\text { leadership. }\end{array}$ \\
\hline
\end{tabular}

On the other hand, a comparative analysis of traditional (classical) leadership theories and modern concepts allows us to draw a number of important conclusions about the most significant distinctive trends in the development of leadership and the teachings about it that have formed in recent decades.

1. Classical theories were mostly univariate, since one variable was taken into account as a determinant of leadership - the personality of the leader, the behavior of the leader, and situational characteristics. Later, the models became combined, mainly two-factor models personal-situational, personal-behavioral, behavioral-situational. This indicates that the current stage of the study of leadership in management is characterized by a systematic approach, as well as a general view of management, i.e. it involves multifactorial concepts.

2.The rationalistic approach to leadership, in which the leader had to use a certain set of rational methods and tools to ensure the effective performance of subordinates, was replaced by an irrational approach, in which leadership is based more on values and emotions.

3. Much attention is paid to the study of the impact on the effectiveness of leadership of gender, age, cultural, national aspects, the problem of interaction of leaders.

4. There is a transition from individual leadership to collective leadership (collegial) based on the construction of a connection of minds between the leader and followers and non-linear trusting and supportive relationships.

5. Transactional leadership, focused on positional power and traditional management techniques through setting tasks and monitoring their implementation, has been replaced by the concepts of transformational leadership, in which the leader inspires followers to make positive changes by creating a common shared vision, influencing the basic attitudes and values of employees, and then the transition to ethical leadership based on ethical and moral values, through the development of followers, the formation of a favorable moral and psychological climate and trust relationships. 
6. The problems of self-motivation of the leader (internal motivation for leadership) have come to the fore, there is a development of leadership «in depth», i.e. self-knowledge, the development of spiritual abilities, personal growth of the leader, the search for his purpose in order to ensure the authenticity of his existence.

Speaking about the prospects for further development of leadership and related management concepts, it is necessary to note the following. The knowledge economy has already begun its transformation into a digital economy, in which the main driving force for ensuring business competitiveness is, as Professor L.V. Lapidus notes, the strategy of digital transformation [25]. Such a business transformation is a very complex process, which significantly complicates the management of an organization undergoing a radical change. Accordingly, in the digital economy, both leadership models and leadership requirements will change.

As G.I. Gumerova and E.Sh. Shaimieva note, the concepts of leadership are undergoing a transformation from the management of explicit knowledge in real space to the management of dominant implicit knowledge in virtual and real spaces [26].

Such a concept as «digital leaders» has already emerged. Their fundamental difference is that they have the ability to learn, solve problems and conduct active transformations, as well as the ability to «feel trends» and make forecasts. In addition to traditional leadership skills, «digital leaders» must have curiosity and intelligence, learning ability and flexibility, and a high risk appetite. Their task is to "set the right tone for the transformation and translate its value to the entire structure of the company» [27].

\section{Conclusions}

Summing up the systematization of modern concepts of leadership, it should be noted that the emergence of new models of leadership is due to both the synthetic nature of the phenomenon of leadership itself, and the ongoing reinterpretation of the perception and understanding of the world as dynamic, constantly changing, risky and complex, the reinterpretation of the system of values and moral guidelines in modern society, which requires a revision of managerial concepts and models of leadership. Modern leadership studies somehow develop the main directions of the study of leaders and leadership, set by classical concepts, but there are significant distinctive trends that have formed in recent decades: the desire for collective leadership, the transition from transactional to transformational leadership, the development of leadership «deep» in the direction of selfmotivation of the leader, largely irrational approach to leadership, which is due to the transition of modern management to the humanistic plane.

\section{References}

1. Filonovich S.R. Leadership as an integral problem of the behavioral sciences // Russian Journal of Management. 2007. Volume 5. No. 4. pp. 91-100.

2. Filonovich S.R. Theories of leadership in management: history and prospects. 2003. №2. URL: $\quad$ https://cyberleninka.ru/article/n/teorii-liderstva-v-menedzhmente-istoriya-iperspektivy

3. Vikhansky O.S., Mirakyan A.G. New millennium: managerial anomalies and modern concepts of leadership // Russian Journal of Management. 2018. №1. URL: https://cyberleninka.ru/article/n/novoe-tysyacheletie-upravlencheskie-anomalii-isovremennye-kontseptsii-liderstva

4. Zamulin A.L. Leadership in the age of knowledge / / Vestnik of S.-Petersburg University. Ser. Management. 2012. Issue 3. pp. 48-77. 
5. Karpinskaya E.O., Shirokova G.V. Entrepreneurial leadership: approaches to the definition and the main directions of research. Vestnik of S.-Petersburg University. Management. 2019. No. 2. URL: https://cyberleninka.ru/article/n/predprinimatelskoeliderstvo-podhody-k-opredeleniyu-i-osnovnye-napravleniya-issledovaniy

6. Krylova T.A. Development of leadership theories in economic science // Economic Journal. 2015. №1 (37). URL: https://cyberleninka.ru/article/n/razvitie-teoriy-liderstvav-ekonomicheskoy-nauke

7. Mosina L.M., Veselovsky D.P. Interdisciplinary approach in the study of the phenomenon of leadership // State University of Management/ Bulletin. 2016. No. 11. URL: $\quad$ https://cyberleninka.ru/article/n/mezhdistsiplinarnyy-podhod-v-izucheniifenomena-liderstva

8. Romanova M.V. Theoretical approaches to the consideration of the problem of leadership in science // The world of science, culture and education. 2010. №1. URL: https://cyberleninka.ru/article/n/teoreticheskie-podhody-k-rassmotreniyu-problemyliderstva-v-nauke

9. Sergeeva S.A. Evolution of philosophical ideas and concepts of leadership / / Army and Society. 2013. №1 (33). URL: https://cyberleninka.ru/article/n/evolyutsiya-filosofskihidey-i-kontseptsiy-liderstva

10. Slinkova O.K. Evolution of views on the nature of leadership // Modern society and power. 2018. №3 (17). URL: http://gmanagement.ru/index.php/ru/arxiv/172018/781 slinkovaok-172018

11. Gubanova A.V. Analysis of prerequisites and directions for the development of leadership studies in management // Economic systems. 2020. Volume 13. No. 4 (51). pp. 91-101.

12. Adizes I. On the threshold of a managerial revolution. In the collection.: How to develop a business in an era of change. Harvard Business Review Russia. 2017. 4-7.

13. Fairholm, G.W. Values Leadership. Toward a New Philosophy of Leadership. - N.Y., 1991.

14. Goleman D. What makes a leader. Harvard Business Review 76 (6): 92-105. 1998.

15. Goleman D. Leadership that gets results. Harvard Business Review 78 (2): 78-94. 2000.

16. Fisher R., Sharp A. Lateral Leadership: Gone When You Are Not the Boss. Harper Colins Business: London. 1998.

17. Bradfort D.L., Cohen A.R. Power Up: Transforming Organizations Through Shared Leadership. Jossey-Bass: San-Francisco. 1998.

18. Lipman-Blumen J. Connective leadership: A new paradigm. Drucker Magazine 1 (1): 12-19, 38. 1997.

19. Lipman-Blumen J. Connective Leadership: Managing in a Changing World. Oxford University Press: Oxford, 2000.

20. Tichy N. The Leadership Engine. Harper Business: N.Y., 1997.

21. Cashman K. Leadership from the Inside Out. Executive Excellence Publishing: Provo, UT, 2001.

22. Goleman D., Boyatzis R., McKee A. Primal leadership: The hidden driver of great performance. Harvard Business Review 79 (12): 42-51. 2001.

23. Trompenaars F., Hampden-Turner C. 21 Leaders for the 21 st Century: How Innovative Leaders Manage in the Digital Age. McGraw-Hill: N.Y., 2002. 
24. Dierendonck D. van. Servant Leadership: A Review and Synthesis // Journal of Management. 2010. - Vol. 37.

25. Lapidus L.V. Digital Leadership Strategies // In the world of science. 2019. № 10. URL: https://scientificrussia.ru/articles/strategii-tsifrovogo-liderstva-v-mire-nauki-102019

26. Gumerova G.I., Shaimieva E.Sh. Intellectual leadership in the digital economy (based on the concept of leadership in the knowledge economy). 2018. №13-1. URL: https://cyberleninka.ru/article/n/intellektualnoe-liderstvo-v-tsifrovoyekonomike-na-osnove-kontseptsii-liderstva-v-ekonomike-znaniy.

27. Digital Leadership: what your CEO should be able to do. URL:https://pro.rbc.ru/demo/5e30321c9a7947c4b2f84 7ae 